\title{
Parasite fauna of wild and cultured dusky-grouper Epinephelus marginatus (Lowe, 1834) from Ubatuba, Southeastern Brazil
}

\author{
Roumbedakis, K. ${ }^{a}$, Marchiori, NC. ${ }^{a}$, Paseto, Á. ${ }^{a}$, Gonçalves, ELT. ${ }^{a}$, Luque, JL. ${ }^{b}$, Cepeda, PB. ${ }^{b}$, \\ Sanches, EG. ${ }^{c}$ and Martins, ML. ${ }^{a}{ }^{*}$ \\ ${ }^{a}$ AQUOS - Laboratory of Aquatic Organisms Health, Aquaculture Department, Federal University of Santa Catarina, \\ Rod. Admar Gonzaga 1346, Florianópolis, SC, Brazil \\ ${ }^{b}$ Departamento de Parasitologia Animal, Curso de Pós-Graduação em Ciências Veterinárias, \\ Universidade Federal Rural do Rio de Janeiro, Instituto de Veterinária, Departamento de Parasitologia Animal, BR 465, \\ km 7 - CEP 23851-970 Seropédica, RJ, Brazil \\ ${ }^{c}$ Núcleo de Pesquisa e Desenvolvimento do Litoral Norte, Instituto de Pesca/APTA/SAA, \\ Rua Joaquim Lauro Monte Claro Neto 2275, Ubatuba, SP, Brazil \\ 'e-mail:mlaterca@cca.ufsc.br \\ Received August 9, 2012 - Accepted October 3, 2012 - Distributed November 29, 2013
}

\begin{abstract}
This study aimed at identifying and quantifying the parasites of wild and cultured dusky grouper Epinephelus marginatus. During a year and thereby all four seasons, 20 wild and 20 cultured groupers were examined for the presence of parasites, except in the last season, in which 19 wild and 20 cultured fish were examined, totalling 159 groupers analysed from Ubatuba, southeastern Brazil. Prevalence, mean intensity of infection, mean abundance and mean relative dominance were calculated. Five species of parasites were identified in fish from both origins: Pseudorhabdosynochus beverleyburtonae (Monogenea), Neobenedenia melleni (Monogenea), Pseudempleurosoma sp. (Monogenea), Helicometrina nimia (Digenea) and larvae of Contracaecum sp. (Nematoda). The prevalence of ectoparasites, in most cases, was higher than endoparasites. The most abundant parasite was the monogenea Pseudorhabdosynochus beverleyburtonae in both wild and cultured fish, along all seasons. Neobenedenia melleni was observed in wild and cultured fish in all seasons, with a gradual increase in the number of parasites from the coldest to the hottest seasons, with the highest prevalence and mean intensity in the summer. Helicometrina nimia was found in all seasons in both wild and cultured fish, except for summer, where its presence was detected only in wild fish. Pseudempleurosoma sp. and larvae of Contracaecum sp. showed low prevalence occurring in wild and cultured fish in the autumn and spring, respectively. This study revealed high intensities of potentially pathogenic parasites that could favour disease outbreaks in culture conditions.
\end{abstract}

Keywords: Serranidae, parasitology, seasonality, Pseudorhabdosynochus beverleyburtonae, Neobenedenia melleni, Helicometrina nimia.

\section{Fauna parasitária da garoupa selvagem e de cultivo Epinephelus marginatus (Lowe, 1834) em Ubatuba, sudeste do Brasil}

\section{Resumo}

Este estudo teve como objetivo identificar e quantificar os parasitos da garoupa verdadeira Epinephelus marginatus selvagem e cultivada. Durante um ano, nas quatro estações, 20 garoupas selvagens e 20 cultivadas foram examinadas quanto à presença de parasitos, exceto na última estação, em que foram examinados 19 peixes selvagens e 20 cultivados, totalizando 159 peixes examinados em Ubatuba, Sudeste do Brasil. A prevalência, intensidade média de infecção, abundância média and dominância média relativa foram calculados. Cinco espécies de parasitos foram identificadas nos peixes de ambas as origens: Pseudorhabdosynochus beverleyburtonae (Monogenea), Neobenedenia melleni (Monogenea), Pseudempleurosoma sp. (Monogenea), Helicometrina nimia (Digenea) e larvas de Contracaecum sp. (Nematoda). A prevalência de ectoparasitos foi, na maioria das vezes, maior do que a de endoparasitos. O parasito mais abundante foi o monogenea Pseudorhabdosynochus beverleyburtonae em ambos os peixes selvagens e cultivados, durante todas as estações. Neobenedenia melleni foi observado e, peixes selvagens e cultivados em todas as estações, com aumento gradativo no número de parasitos das estações mais frias para as mais quentes, com as maiores prevalências e intensidades médias no verão. Helicometrina nimia foi encontrado em todas as estações em ambos os peixes selvagens e cultivados, exceto no verão, em que foi observada sua presença apenas em peixes selvagens. Pseudempleurosoma sp. e larvas de Contracaecum sp. apresentaram baixas prevalências, ocorrendo 
em peixes selvagens e cultivados no outono e na primavera, respectivamente. Este estudo revelou altas intensidades de parasitos potencialmente patogênicos que podem favorecer surtos de doenças em situações de cultivo.

Palavras-chave: Serranidae, parasitologia, sazonalidade, Pseudorhabdosynochus beverleyburtonae, Neobenedenia melleni, Helicometrina nimia.

\section{Introduction}

Dusky grouper Epinephelus marginatus (Lowe, 1834 ) is a serranid teleost that inhabits rocky and protected areas, usually in shallow waters, eventually reaching a depth of 200 metres, widely distributed, from the southern coast of Brazil, across the Mediterranean and East Atlantic in the British Islands to South Africa, Azores, Madeira and Canary Islands and Cape Verde Islands (Heemstra and Randall, 1993).

Groupers are fish of great commercial value and they constitute an important item in coastal fisheries in the tropics. However, due to the decline of not only the fishing of grouper, but also several species of marine fish, mariculture has been used to increase fish production. Considered as an economically important species, dusky grouper is a potential candidate for marine aquaculture in Brazil (Sanches et al., 2006).

Parasites normally found in wild fish populations, in most cases may also be responsible for diseases in aquaculture (Scholz, 1999). Conditions associated with intensive aquaculture as confinement, overpopulation and stress may facilitate the transmission of parasites and increase parasite intensity in farmed fish (Ogawa et al., 1995). Such diseases restrict the development and sustainability of the aquaculture industry and lead to direct production losses (Bondad-Reantaso et al., 2005).

Despite the considerable progress in fish parasitology in recent decades, there are still major gaps in knowledge of taxonomy, biology, epizootiology and parasites control. In addition, studies on the parasitology of Brazilian marine cultured fish can be considered incipient when compared to freshwater fish culture. From this assumption, the present study aimed to analyze the parasitic fauna of wild and cultured dusky grouper in different seasons, from southeastern Brazil.

\section{Materials and Methods}

Fish from Ubatuba, on the coast of São Paulo, southeastern Brazil (2326'20” S, 4501'37' W) were examined during the four seasons, between July/2009 and June/2010, 20 wild and 20 cultured in each season (Ethics committee CEUA/UFSC 23080.029981/2009-76, IBAMA 21715-1). Cultured fish were kept in floating net cages of $8 \mathrm{~m}^{3}$ made of multifilament's nylon with $25 \mathrm{~mm}$ mesh size and stocked at a density of nine fish per tank. Cages were attached to a system of a "long line" mounted and fixed to $20 \mathrm{~m}$ parallel to the coastline, at a water depth of $4.0 \pm 0.5 \mathrm{~m}$. The floating net cages were cleaned every 30 days, in order to maintain an adequate circulation of sea water. Fish were fed with trash fish, of which were removed head and viscera. Wild fish were caught with baited traps and maintained in $3000 \mathrm{~L}$ tank with closed recirculation system and constant aeration in laboratory for a period of 10 days and fed every 2 days with trash fish. This time was standardised comprehending to the period between the time of capture and sampling.

In the sample period, the water temperature and salinity in the place of culture were monitored. After biometry, fish were anesthetised with a solution of benzocaine $\left(50 \mathrm{mg} \mathrm{L}^{-1}\right)$, euthanized and necropsied for parasitological analysis. The mucus of body surface, gills, stomach and intestine were collected and fixed separately and subsequently analysed for the presence of parasites.

The parasites were collected and fixed according to Kritsky et al. (1995) and Eiras et al. (2006) and quantified under stereomicroscope. Monogenea were stained with Gomori's trichrome solution, mounted on permanent slides with Canada balsam or mounted directly in Hoyer's medium for identification according to Jahn and Kuhn (1932) and Yamaguti (1965) and the redescriptions of Whittington and Horton (1996) and Santos et al. (2000). Digeneans were stained with Mayer's carmine, cleared in beechwood creosote, mounted on permanent slides with Canada balsam for identification according to Jones et al. (2005), Linton (1910) and Hafeezullah (1971). The nematodes were mounted in semi-permanent preparations in Amann lactophenol and made drawings and measurements for comparison with the specialised literature (Hartwich, 1974; Vicente and Pinto, 1999).

The data of prevalence, mean intensity and mean abundance of parasites were calculated using the software Quantitative Parasitology ${ }^{\circledR} 3.0$ (Reiczigel and Rózsa, 2005) and mean relative dominance as suggested by Rohde et al. (1995). The data were transformed to the square root of $\mathrm{x}$, subjected to analysis of variance and when significant to Tukey's test to compare the means while adopting a significance level of 5\%. The parasitological indices were compared between wild and cultured throughout the period regardless of the season and also within each season.

\section{Results}

The mean water temperature in cages in the period was $24.05 \pm 1.48^{\circ} \mathrm{C}$, reaching maximum value in Febru$\operatorname{ary} / 2010\left(27.80{ }^{\circ} \mathrm{C}\right)$ and minimal in June/2010 $\left(21.80{ }^{\circ} \mathrm{C}\right)$. Salinity remained stable, ranging between 33.26 and 36.30 ppt. Table 1 shows the biometric characteristics of cultured and wild fish during the study period.

The species of monogenean ectoparasites identified in grouper were Pseudorhabdosynochus beverleyburtonae (Oliver, 1984) Kritsky and Beverley-Burton, 1986 (Diplectanidae) in the gills and Neobenedenia melleni (MacCallum, 1927) Yamaguti, 1963 (Capsalidae) on the 
Table 1 - Mean values of total length and weight followed by standard error with minimum and maximum values in parenthesis of wild and cultured dusky grouper Epinephelus marginatus from Ubatuba, São Paulo, Brazil during the four seasons. N: number of examined fish.

\begin{tabular}{llll}
\hline Origin of fish/ Seasons & N & Total length $(\mathbf{c m})$ & Weight $(\mathbf{g})$ \\
\hline Wild fish & & & \\
Winter (July/09) & 20 & $30.01 \pm 0.64(26.5-37.0)$ & $370.36 \pm 25.74(248.7-677.7)$ \\
Spring (September/09) & 20 & $28.15 \pm 0.25(20.9-34.8)$ & $323.85 \pm 34.90(82.5-629.4)$ \\
Summer (February/10) & 20 & $27.07 \pm 0.62(22.5-31.5)$ & $260.82 \pm 18.28(132.1-414.1)$ \\
Autumn (June/10) & 19 & $32.51 \pm 1.12(27.0-42.0)$ & $531.21 \pm 61.00(259.2-1117.8)$ \\
Cultured fish & & & \\
Winter (July/09) & 20 & $28.90 \pm 0.87(21.0-36.5)$ & $339.80 \pm 30.29(140.5-650.1)$ \\
Spring (September/09) & 20 & $31.25 \pm 0.84(25.0-40.3)$ & $433.59 \pm 36.80(240.4-939.2)$ \\
Summer (February/10) & 20 & $32.62 \pm 1.45(21.0-46.0)$ & $539.75 \pm 70.67(127.0-1392.9)$ \\
Autumn (June/10) & 20 & $21.81 \pm 1.26(13.0-30.2)$ & $177.38 \pm 26.70(25.5-409.4)$ \\
\hline
\end{tabular}

body surface. Regarding the endoparasites, these were identified: a species of digenean Helicometrina nimia Linton, 1910 in the stomach and intestine, a monogenean Pseudempleurosoma sp. was observed free in the stomach and one species of nematode, Contracaecum sp. in the mesentery.

Wild fish showed similar prevalence, mean abundance and mean intensity of infection by $P$. beverleyburtonae and $H$. nimia for cultured fish. Neobenedenia melleni presented higher abundance and mean intensity of infection in cultured fish (16.30 and 23.29) than in wild fish (3.22 and 5.16). Pseudempleurosoma sp. and larvae of Contracaecum sp. have prevalence below 10\% and low mean intensities of infection (Table 2).

The most prevalent and abundant parasite $(\mathrm{p}<0.05)$ was $P$. beverleyburtonae with a prevalence of $100 \%$ in fish of both origins during all seasons, except for cultured fish in the summer $(95 \%)$. The highest mean abundance occurred in the autumn in both wild (1350.58) and cultured (2077.80) fish. This species was one of the most relative dominant parasites, with levels above 0.70 in all seasons in fish of both origins (Table 3 ).

Neobenedenia melleni was observed in wild and cultured fish in all seasons, increasing the number from the colder to the hottest seasons. Prevalence was significantly lower $(\mathrm{p}<0.05)$ in wild fish in the autumn $(26.3 \%)$ than that related in cultured ones in the summer $(100 \%)$. Higher values $(p<0.05)$ of abundance and mean intensity of infection (52.75) were found in cultured fish in the summer (Table 3).

Pseudempleurosoma sp. were found in wild and cultured fish only in the autumn, with a prevalence of $5.26 \%$ and $30 \%$, respectively, and mean abundance and mean intensity of infection 0.05 and 1.0 in wild groupers and 0.75 and 2.5 in cultured groupers, respectively (Table 3 ).

Helicometrina nimia was observed in all seasons in groupers of both origins, except for the summer, in which it occurred only in wild fish. The highest prevalence was observed in the autumn, in both wild $(31.6 \%)$ and cultured fish $(60 \%)$ and the highest mean intensity of infection occurred in the winter in wild fish (11) and autumn in cultured fish (4.33) (Table 3).

Contracaecum sp. larvae were observed only in spring, in both wild and cultured fish, with low prevalence (5\% in wild and $15 \%$ in cultured fish) and mean abundance of infection ( 0.05 in wild and 0.15 in cultured fish) (Table 3).

\section{Discussion}

Several factors can determine or influence the parasitic fauna of many species or groups of hosts, such as age, sex, size, type of food, lifestyle, geographical and seasonal distribution of population of the host in time and space (Dogiel, 1964). Main and Rosenfeld (1996) suggest that diseases in culture environments are not caused by a single factor but a combination of interrelated factors that make the fish more susceptible to pathogens. In addition, parasites with monoxenic life cycle can proliferate quickly in these conditions increasing significantly in a short period of time.

Studies on the parasitic fauna of marine fish have shown that dominant parasites in a particular host species tend to be the same, regardless of whether the fish is wild or cultured. However, the number of parasites in cultured fish is usually superior to wild fish (Rückert at al., 2010). In this study, in most cases, there were no significant differences in the parasites load, especially for monogenean, between wild and cultured fish in the seasons. This might be related to the fact that it was not possible to capture wild fish all on the same day and these were kept in the laboratory for a period of 10 days until analysis, which may have contributed to a significant increase in the number of parasites on these fish.

In relation to parasite species richness, Leong and Wong (1988) found 16 species of parasites in wild $E$. malabaricus (Bloch and Schneider, 1801) and 11 species 
Roumbedakis, K. et al.

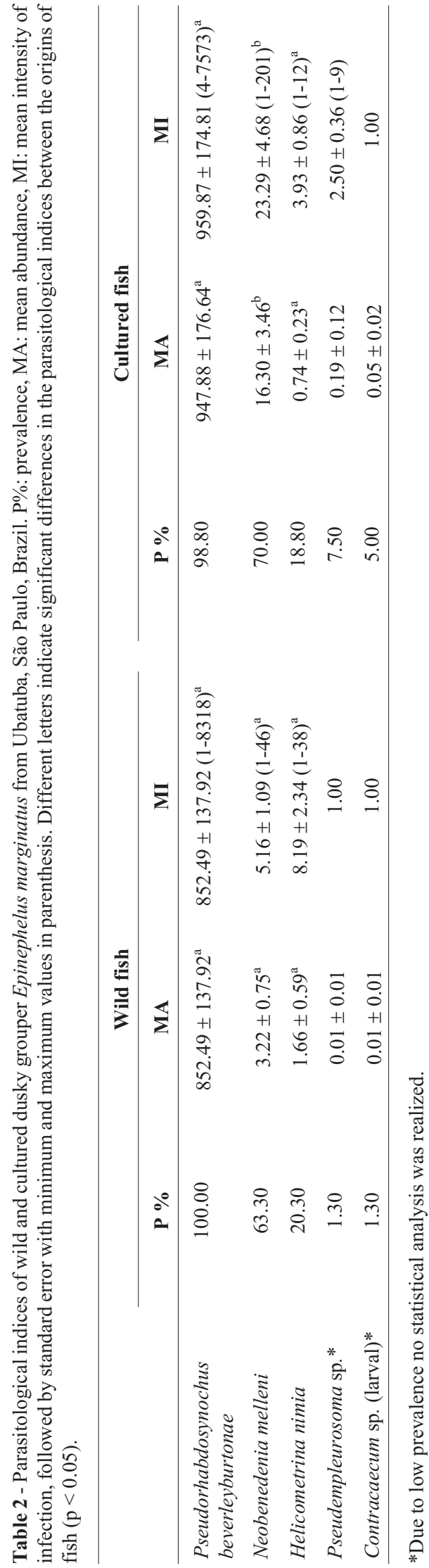

in cultured fish, of which only six were common to both origins. Rückert et al. (2010) also found higher parasite species richness in wild Epinephelus fuscoguttatus (Forsskål, 1775) (30) in relation to cultured fish (25). These authors found, in most cases, higher prevalence of ectoparasites on E. malabaricus and E. fuscoguttatus compared to endoparasites. The values of prevalence of ectoparasites and endoparasites found in this study corroborate the findings of Leong and Wong (1988) and Rückert et al. (2010), but there was no difference in the parasitic fauna of wild and cultured fish, in which the same species of parasites (5) in fish of both origins were found.

Serranid fishes, especially Epinephelus spp. are commonly parasitized by diplectanid monogenean. Most diplectanids that affect groupers belong to the genus Pseudorhabdosynochus and parasitize its gills. Representatives of this genus induce pathological conditions in cultured fish (Leong and Wong 1988, Santos et al., 2000). According to Leong (1997), Pseudorhabdosynochus infections on these fish are directly related to stocking density and can be considered a constant source of stress, which is the main factor that contributes to disease outbreaks. In Brazil, P. beverleyburtonae was reported parasitizing the gills of wild E. marginatus (Santos et al., 2000). In the present study this species was also reported in cultured specimens, beyond the wild ones. In fact, this could be explained by the proximity between animals kept in cages and the wildlife that inhabit the rocks next to the culture structures.

Pseudorhabdosynochus epinepheli Yamaguti, 1958 was appointed by Leong and Wong (1988) as the most abundant parasite in E. malabaricus, with prevalence $100 \%$ in cultured fish and $94 \%$ in wild fish and a mean intensity of infection threefold higher in cultured fish. Rückert et al. (2010) identified P. epinepheli and Pseudorhabdosynochus lantauensis (Beverley-Burton and Suriano, 1981) Kritsky and Beverley-Burton, 1986 as the most abundant parasites in wild and cultured E. fuscoguttatus during three consecutive seasons, two rainy and one wet. However these authors did not verify parasite's seasonality. In the present study, higher rates of parasitism (intensity of infection and abundance) observed in cultured fish mainly in the winter, spring and autumn can become a limiting factor for success in grouper production. The appropriate management and population density of cultivation, as well as the large distance between the rocky and cultivation structures can prevent parasite proliferation and transmission in floating net cages.

Luo and Yang (2010) noted the seasonality influence in parasitism by Pseudorhabdosynochus coioidesis $\mathrm{Bu}$, Leong, Wong and Woo Foo, 1999 and Pseudorhabdosynochus serrani (Yamaguti, 1953) in wild grouper [Epinephelus coioides (Hamilton, 1822)] and under experimental polyculture conditions [E. coioides, Epinephelus awoara (Temminck and Schlegel, 1842) and Epinephelus bruneus (Bloch, 1793)]. In wild fish, the authors reported the presence of these monogeneans only in the autumn and winter, with prevalence and mean inten- 


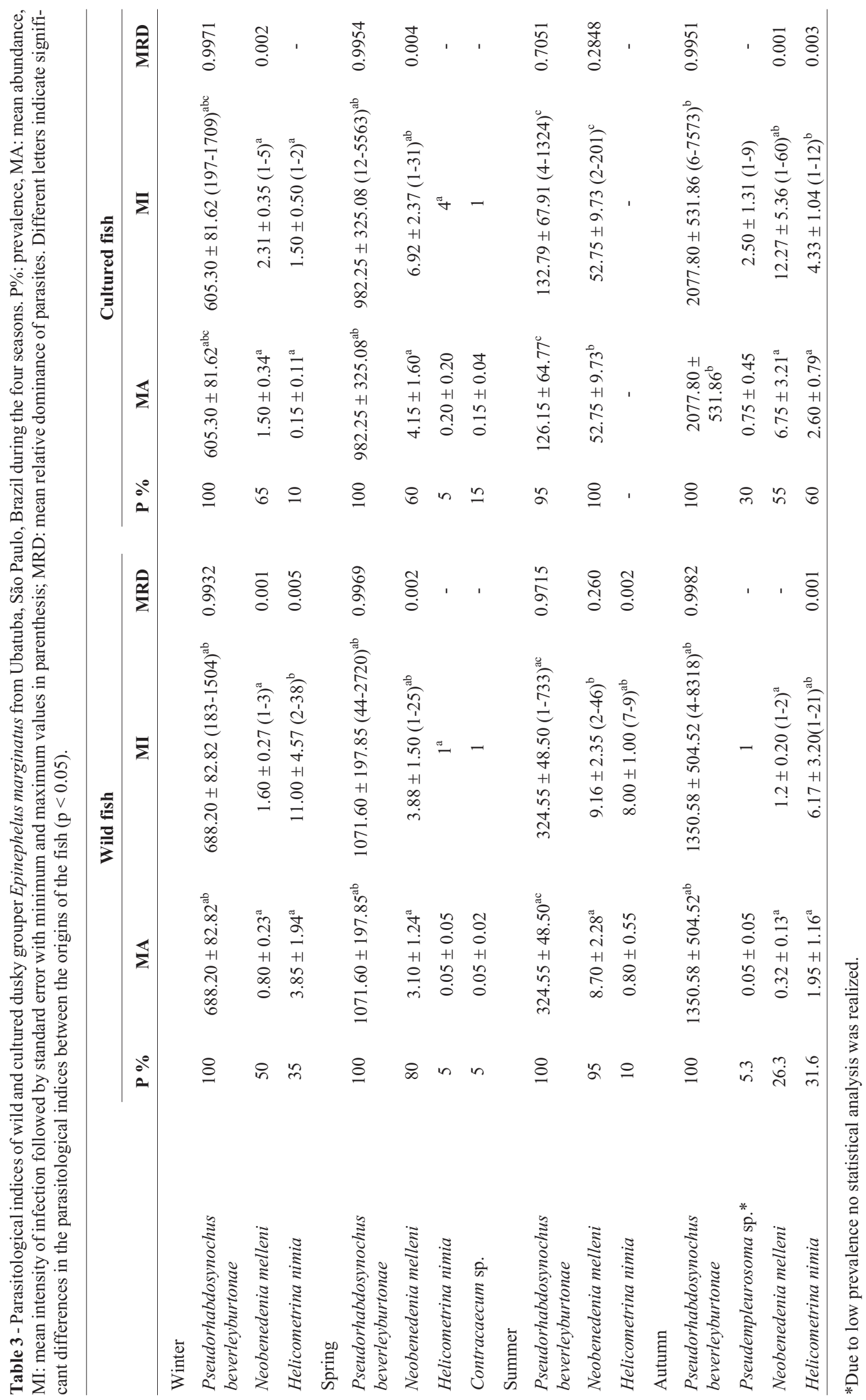


sity of infection of both species higher in the winter. The prevalence and mean intensity of both parasites in polyculture showed the same pattern of seasonal fluctuation, reaching the maximum values in the autumn, except for the prevalence of $P$. serrani, whose maximum value was found in winter. On the other hand, in the present study, the diplectanid $P$. beverleyburtonae was the most prevalent and abundant parasite in wild and cultured fish in all seasons. The highest values of mean intensity of this parasite occurred in autumn in both wild and cultured fish, but prevalence was similar in all seasons and similar to the findings of Leong and Wong (1988).

Neobenedenia melleni is known for low host specificity, being found in more than 100 species comprising more than 30 families of five orders of wild and cultured teleosts (Whittington and Horton, 1996). However, there is no detailed information about the injury or disease in wild hosts. On the other hand, cultured and ornamental fish routinely develop severe infections by this parasite (Whittington and Horton, 1996). According to Carvalho and Luque (2009), studies of naturally infected wild hosts are important indicators for knowledge of the population of N. melleni, registers of new hosts and new geographic areas. Moreover, it can assist in management and aquaculture thereby preventing and controlling diseases associated with infections (Bullard et al., 2003).

In the Caribbean, Sikkel et al. (2009) studied three wild congeners species of surgeonfishes (Acanthurus coeruleus, Acanthurus bahianus and Acanthurus chirurgus) collected from the same sites and observed differences in parasitological indexes between the species. The authors attributed these findings to differences in the physiology of fish that can affect the susceptibility to infection, the habitat use, which can vary in densities of infective stages of the parasites, and the difference in species access to cleaner organisms that remove parasites. Additionally, the authors also observed differences among site and between-year which were attributed to biotic and abiotic factors, such as host density, immune function and water quality in captive and wild conditions.

In cultivated fish, Deveney et al. (2001) registered an outbreak of $N$. melleni that occurred on barramundi Lates calcarifer cultivated in sea cages in Australia, which resulted in the loss of 200.000 fish (approximately 50 tones) in three weeks, but the origin of the outbreak remains unknown. Presumably, this parasite lives naturally on one or, perhaps, several local fish species near to the barramundi farm which provided a rapid proliferation in cultured fish when sea temperatures dropped and probably compromise the immunological defences of $L$. calcarifer combined with the high fish density in the sea cages (Deveney et al., 2001). In Brazil, N. melleni was recorded parasitising cultured E. marginatus (Sanches and Vianna, 2007) and Rachycentron canadum (Linnaeus, 1766) (Kerber et al., 2011) in floating net cages. In this study, $N$. melleni was found in wild and cultured $E$. marginatus, which was the first record of this parasite in wild specimens of dusky grouper.
Temperature is known to be a key factor that affects the life cycle of capsalid monogenean. Hirazawa et al. (2010) verified that higher temperatures were responsible for faster growth rate and maturation of Neobenedenia girellae (Hargis, 1955) Yamaguti, 1963 (considered synonymy of N. melleni by Whittington and Horton, 1996) when compared to lower temperatures. In this study, the highest prevalence and intensities of $N$. melleni were significantly higher in cultured fish in the summer, which may be related to higher temperatures during this season. In addition, the direct life cycle of this parasite facilitates its spread in culture conditions.

It is estimated that over than $95 \%$ of monogenean are ectoparasites found on gills or skin of fish (Euzet and Combes, 1998), however some are known to be adapted to survive in the internal organs (Santos et al., 2001). The monogenean Pseudempleurosoma gibsoni Santos et al., 2001 was described in the esophagus of Paralonchurus brasiliensis (Steindachner, 1875) from Ubatuba, São Paulo, Brazil (Santos et al., 2001). In the present study, the presence of specimens of this genus from the same locality was observed free in the stomach of E. marginatus, not adhered in the mucosa. It is possible that this species has displaced from the esophagus and, therefore, was observed in the stomach. Due to small number of specimens found, it was not possible to identify the parasite in specific level, but this is the first record of the genus in groupers from Brazil.

Helicometrina nimia Linton, 1910 is a digenean endoparasite recorded in several species of marine fish, including several species of Serranidae (Cribb et al., 2002). This species has a wide spectrum of hosts and geographical distribution that is noticeably wider than other species of the genus (Oliva and Muñoz, 1985). In grouper, it was recorded in Epinephelus analogus (Sogandares-Bernal, 1959), Epinephelus diacantus (Bilqees, 1981) and Epinephleus morio (Moravec et al., 1997). Moravec et al. (1997) found prevalence of $15 \%$ and mean intensity of infection by $H$. nimia of one parasite. In this study, the prevalence ranged between 0 and $60 \%$, with mean intensities of infection between 1 and 11 parasites.

Luque and Poulin (2004) reported the occurrence of anisakid larvae in 44 species of marine fish from the Rio de Janeiro coast. Larvals of Contracaecum sp. are anisakid species that occurs in several species of fish and, in groupers, was reported by Leong and Wong (1988) in E. malabaricus with prevalence and mean intensities of infection of 2.9 and 1.0 in wild fish and 1.6 and 1.0 in cultured fish. In this study, the larvae of Contracaecum sp. were found in wild and cultured fish only in the spring, with low prevalence and intensities, corroborating the results of Leong and Wong (1988).

Parasites with heteroxenic life cycle depend on intermediate hosts to complete its life cycle. Consequently, the rate of infection in cultured fish, with the exception of direct infection by parasites in free-swimming life stages, depends on the access to their intermediate hosts, by the availability of live prey or fresh food untreated (Rückert et al., 2009). Leong and Wong (1988) attributed the 
higher prevalence of endoparasites in cultured fish to the food, which comprised trash fish. Rückert et al. (2009) found that cultured fish fed with pellets food had fewer endoparasites compared to trash fish fed groupers. In this study, no significant difference between the total number of endoparasites of wild and cultured fish were observed. Fish were fed with trash fish, without the head and viscera, which might have reduced the transmission of parasites through food.

In conclusion, the richness of parasites and the prevalence, abundance and mean intensity of infection observed in E. marginatus were in most cases similar in wild and cultured fish. The seasonality influenced the occurrence of parasites. High intensities of potentially pathogenic parasites were observed, which could promote disease outbreaks in culture conditions.

\section{Acknowledgments}

The authors thank the National Council of Scientific and Technological development (CNPq) for the Master's degree scholarship to $\mathrm{K}$. Roumbedakis (CNPq 553199/2009-9) and the research productivity fellowship to Dr. M. L. Martins (CNPq 302493/2010-7), the Fisheries Institute, Ubatuba, SP, Brazil for support in field sampling and to Dr. J.L.P. Mouriño (Marine Shrimp Laboratory, University of Santa Catarina, SC, Brazil) for his critical review of the manuscript before submission. J. L. Luque was supported by a research fellowship of the Conselho Nacional de Desenvolvimento Científico e Tecnológico (CNPq) of Brazil.

\section{References}

BILQEES, FM., 1981. Digenetic Trematodes Fishes of Karachi Coast. Karachi: Kifayat Academy, 207 p.

BONDAD-REANTASO, MG., SUBASINGHE, RP., ARTHUR, JR., OGAWA, K., CHINABUT, S., ADLARD, R., TAN, Z. and SHARIFF, M., 2005. Diseases and health management in Asian aquaculture. Veterinary Parasitology, vol. 132, no. 3-4, p. 249-272.

BULLARD, SA., GOLDSTEIN, RJ., HOCKING, R. and JEWEL, J., 2003. A new geographic locality and three new host records for Neobenedenia melleni (MacCallum) (Monogenea: Capsalidae). Gulf and Caribbean Research, vol. 15 , no. 1, p. 1-4.

CARVALHO, AR. and LUQUE, JL., 2009. Ocorrência de Neobenedenia melleni (Monogenea; Capsalidae) em Trichiurus lepturus (Perciformes; Trichiuridae), naturalmente infestados, no litoral do Rio de Janeiro, Brasil. Brazilian Journal of Veterinary Parasitology, vol. 18 , no. 1, p. 74-76.

CRIBB, TH., BRAY, RA., WRIGHT, T. and PICHELIN, S., 2002. The trematodes of groupers (Serranidae: Epinephelinae): knowledge, nature and evolution. Parasitology, vol. 124, p. 23-42.

DEVENEY, MR., CHISHOLM, LA. and WHITTINGTON, ID., 2001. First published record of the pathogenic monogenean parasite Neobenedenia melleni (Capsalidae) from Australia. Diseases of Aquatic Organisms, vol. 46, no. 1, p. 79-82.

DOGIEL, VA., 1964. General Parasitology. Edinburgh: Oliver and Boyd. 516 p.
EIRAS, JC., TAKEMOTO, RM. and PAVANELLI, GC., 2006. Métodos de estudo e técnicas laboratoriais em parasitologia de peixes. Maringá: Eduem. 199 p.

EUZET, L. and COMBES, C., 1998. The selection of habitats among the monogenea. International Journal for Parasitology, vol. 28, no. 10, p. 1645-1652.

HAFEEZULLAH, M., 1971. A review on the validity of Helicometrina Linton, 1910 and Stenopera Manter, 1933 (Trematoda). Acta Parasitologica Polonica, vol. 19, p. 133-139.

HARTWICH, G., 1974. Keys to genera of the Ascaridoidea. In ANDERSON,RC., CHABAUD, AG. and WILLMOTT, S. (Eds.). CIH keys to the nematode parasites of vertebrates, no. 2, London: Farnham Royal; Commonwealth Agricultural Bureaux. p. 15.

HEEMSTRA, PC. and RANDALL, JE., 1993. Groupers of the world (family Serranidae, subfamily Epinephelinae) : an annotated and illustrated catalogue of the grouper, rockcod, hind, coral grouper and lyretail species known to date. Rome: FAO. 382 p. FAO species catalogue, vol. 16.

HIRAZAWA, N., TAKANO, R., HAGIWARA, H., NOGUCHI, M. and NARITA, M., 2010. The influence of different water temperatures on Neobenedenia girellae (Monogenea) infection, parasite growth, egg production and emerging second generation on amberjack Seriola dumerili (Carangidae) and the histopathological effect of this parasite on fish skin. Aquaculture, vol. 299, no. 1-4, p. 2-7.

JAHN, TL. and KUHN, LR., 1932. The life history of Epibdella melleni Maccallum, 1927, a monogenetic trematode parasitic on marine fishes. Biological Bulletin, vol. 62, no. 1, p. 89-111.

JONES, A., BRAY, RA. and GIBSON, DI. (Eds), 2005. Keys to the Trematoda. Vol. 2. Wallingford: CAB International. $745 \mathrm{p}$.

KERBER, CE., SANCHES, EG., SANTIAGO, M. and LUQUE, JL., 2011. First record of Neobenedenia melleni (Monogenea: Capsalidae) in sea-farmed cobia (Rachycentron canadum) in Brazil. Revista Brasileira de Parasitologia Veterinária, vol. 20, no. 4, p. 331-333.

KRITSKY, DC., BOEGER, WA. and POPAZOGLO, F., 1995. Neotropical Monogenoidea. 22. Variation in Scleroductus species (Gyrodactylidea, Gyrodactylidae) from siluriform fishes of southeastern Brazil. Journal of Helminthology, vol. 62 , no. 1 , p. 53-65.

LEONG, TS., 1997. Control of parasites in cultured marine finfishes in Southeast Asia - an overview. International Journal for Parasitology, vol. 27, no. 10, p. 177-184.

LEONG, TS. and WONG, SY., 1988. A comparative study of the parasite fauna of wild and cultured grouper (Epinephelus malabaricus Bloch and Schneider) in Malaysia. Aquaculture, vol. 68, no. 3, p. 203-207.

LINTON, E., 1910. Helminth fauna of the Dry Tortugas II. Trematodes. Washington: Carnegie Institution. p. 11-98. Papers from the Tortugas Laboratory of the Carnegie Institute, vol. 4.

LUO, YF. and YANG, TB., 2010. Seasonal population dynamics of the monogeneans Pseudorhabdosynochus coioidesis and $P$. serrani on wild vs. cultured groupers in Daya Bay, South China Sea. Helminthologia, vol. 47, no. 4, p. 241-250.

LUQUE, JL. and POULIN, R., 2004. Use of fish as intermediate hosts by helminth parasites. Acta Parasitologica, vol. 49, no. 4, p. 353-361. 
MAIN, KL. and ROSENFELD, C., 1996. Aquaculture health management strategies for marine fishes : proceedings of a workshop in Honolulu, Hawaii, October 9-13, 1995. Waimanolo, USA.: Oceanic Institute. p. 9-13.

MORAVEC, F., VIDAL-MARTÍNEZ, VM., VARGAS-VÁZQUEZ, J., VIVAS-RODRÍGUEZ, C., GONZÁLEZ-SOLÍS, D., MENDOZAFRANCO, E., SIMÁ-ALVAREZ, R. and GUEMEZ-RICALDE, J., 1997. Helminth parasites of Epinephelus morio (Pisces: Serranidae) of the Yucatan Peninsula, southeastern Mexico. Folia Parasitologica, vol. 44, no. 4, p. 255-266.

OGAWA, K., BONDAD-REANTASO, MG., FUKUDOME, M. and WAKABAYASHY, H., 1995. Neobenedenia girellae (Hargis, 1955) Yamaguti 1963 (Monogenea: Capsalidae) from cultured marine fishes of Japan. Journal of Parasitology, vol. 81, no. 2, p. 223-227.

OLIVA, ME. and MUÑOZ, MA., 1985. Helicometra fasciata (Rudolphi, 1819) y Helicometrina nimia Linton, 1910 (Trematoda: Opecoelidae) en peces marinos de la II Región, Chile. Parasitología al Dia, vol. 9, p. 107-111.

REICZIGEL, J. and RÓZSA, L., 2005. Quantitative Parasitology 3.0. Available from: http://www.zoologia.hu/qp/qp. html. Accessed in: $18 \mathrm{Jul} .2011$.

ROHDE, K., HAYWARD, C. and HEAP, M., 1995. Aspects of the ecology of metazoan ectoparasites of marine fishes. International Journal for Parasitology, vol. 25, no. 8, p. 945-970.

RÜCKERT, S., KLIMPEL, S., AL-QURAISHY, S., MEHLHORN H. and PALM, HW., 2009. Transmission of fish parasites into grouper mariculture (Serranidae: Epinephelus coioides (Hamilton, 1822)) in Lampung Bay, Indonesia. Parasitology Research, vol. 104, no. 3, p. 523-532.

RÜCKERT, S., KLIMPEL, S. and PALM, HW., 2010. Parasites of cultured and wild brown-marbled grouper Epinephelus fuscoguttatus (Forsskål, 1775) in Lampung Bay, Indonesia. Aquaculture Research, vol. 41, no. 8, p. 1158-1169.

SANCHES, EG., HENRIQUES, MB. and FAGUNDES, L., 2006. Viabilidade econômica do cultivo da garoupa-verdadeira Epinephelus marginatus em tanques-rede, região
Sudeste do Brasil. Informações econômicas, vol. 36, no. 12 , p. $15-25$.

SANCHES, EG. and VIANNA RT., 2007. Ocorrência de Neobenedenia melleni (Monogenea: Capsalidae) em garoupa-verdadeira Epinephelus marginatus (Lowe, 1834) cultivada em tanques-rede. Arquivos de Ciências do Mar, vol. 40, no. 2, p. 96-100.

SANTOS, CP., BUCHMANN, K. and GIBSON, DI., 2000. Pseudorhabdosynochus spp. (Monogenea: Diplectanidae) from the gills of Epinephelus spp. in Brazilian waters. Systematic Parasitology, vol. 45, no. 2, p. 145153.

SANTOS, CP., MOURÃO, ED. and CARDENAS, MQ., 2001. Pseudempleurosoma gibsoni $\mathrm{n} . \quad \mathrm{sp}$. , a new Ancyrocephalid Monogenean from Paralonchurus brasiliensis (Sciaenidae) from off the Southeastern Coast of Brazil. Memórias do Instituto Oswaldo Cruz, vol. 96, no. 2, p. 215-219.

SCHOLZ, T., 1999. Parasites in cultured and feral fish. Veterinary Parasitology, vol. 84, no. 3-4, p. 317-335.

SIKKEL, PC., NEMETH, D., MCCAMMON, A. and WILLIAMS JR, EH., 2009. Habitat and Species Differences in Prevalence and Intensity of Neobenedenia melleni (Monogenea: Capsalidae) on Sympatric Caribbean Surgeonfishes (Acanthuridae). Journal of Parasitology, vol. 95 , no. 1 , p. 63-68.

SOGANDARES-BERNAL, F., 1959. Digenetic trematodes of marine fishes from the Gulf of Panama and Bimini, British West Indies. Tulane Studies in Zoology, vol. 7, no. 3, p. 71-117.

VICENTE, JJ. and PINTO, RM., 1999. Nematóides do Brasil. Nematóides de peixes. Atualização: 1985-1998. Revista Brasileira de Zoologia, vol. 16, no. 3, p. 561-610.

WHITTINGTON, ID. and HORTON, MA., 1996. A revision of Neobenedenia Yamaguti, 1963 (Monogenea: Capsalidae) including a redescription of $N$. melleni (MacCallum, 1927) Yamaguti, 1963. Journal of Natural History, vol. 30 , no. 8, p. 1113-1156.

YAMAGUTI, S., 1965. New monogenetic trematodes from Hawaiian fishes, I. Pacific Science, vol. 19, no. 1, p. 55-95. 